\title{
Organizational innovation in the multinational enterprise: internalization theory and business history
}

Article

Accepted Version

Casson, M., Jones, G. and da Silva Lopes, T. (2019) Organizational innovation in the multinational enterprise: internalization theory and business history. Journal of International Business Studies, 50 (8). pp. 1338-1358. ISSN 1478-6990 doi: https://doi.org/10.1057/s41267-018-0156-6 Available at https://centaur.reading.ac.uk/77800/

It is advisable to refer to the publisher's version if you intend to cite from the work. See Guidance on citing.

To link to this article DOI: http://dx.doi.org/10.1057/s41267-018-0156-6

Publisher: Palgrave Macmillan

All outputs in CentAUR are protected by Intellectual Property Rights law, including copyright law. Copyright and IPR is retained by the creators or other copyright holders. Terms and conditions for use of this material are defined in the End User Agreement.

www.reading.ac.uk/centaur 
Central Archive at the University of Reading

Reading's research outputs online 
Organizational Innovation in the Multinational Enterprise:

Internalization Theory and Business History

\begin{abstract}
This research note engages in a methodological experiment by using historical evidence to challenge a common misperception about internalization theory. The theory has often been criticized for maintaining that it assumes a hierarchically organized MNE based on knowledge flowing from the home country. This is not an accurate description of how global firms operate in recent decades, but this note shows it has never been true historically. Using longitudinal data on individual firms from the nineteenth century onwards, it reveals evidence of how entrepreneurs and firms with multinational activity faced by market imperfections changed the design of their headquarters and their organizational structures.
\end{abstract}




\title{
Organizational Innovation in the Multinational Enterprise:
}

\author{
Internalization Theory and Business History
}

\section{Introduction}

Recently there have been multiple assertions that "history matters" in IB, although overcoming the methodological roadblocks to making it matter remains a work in progress (Jones and Khanna, 2006; Buckley 2009; Jones and Pitelis, 2015; Verbeke and Kano, 2015). This note offers a concrete example of the value of bridging the gap between IB theory and history which speaks directly to recent calls for addressing big questions and employing multidisciplinary perspectives (Buckley et al., 2017). It presents compelling new evidence about how entrepreneurs and firms with multinational activity faced by market imperfections in the nineteenth century changed the design of their headquarters roles and their organizational structures rather than changing their entry modes. This phenomenon is well-known in contemporary global business, and has erroneously been used to criticize internalization theory. The contribution of this note is to show that there is absolutely nothing new about this strategy.

It is well-established that the multinational enterprise (MNE) as an organizational form has been around since the nineteenth century (Wilkins, 1970, 1974; Jones, 2005a). Historical research on MNEs is often informed by the classic internalization theory proposed by Buckley and Casson (1976) to explain the emergence of the modern, internationally operating firm (for example Wilkins, 1998; Jones, 2000, 2005a; Lopes, 2007, 2010; Verbeke and Kano, 2015; among others).

One interesting element that arises, when looking at MNE historical trajectories, is the diversity of organizational forms employed across time. The past does not present us with what could be interpreted as a simplified version of today's modern corporation. Instead the past reveals organizational forms that were (and are) novel, often complex, and uncommon. To use a biological analogy, it is not a single exotic animal that historians discover, but rather an entire zoo (Wilkins, 1988, 1998; Jones, 1986; Dunning, 1993; Rugman and Verbeke, 1992; and Birkinshaw et al, 2006). For the most part, the diversity of these firms has not been addressed explicitly by internationalization theory. Revisiting this past provides an important opportunity for the usefulness of theory to be tested in "new settings."

Historical research shows that the modern MNE emerged from a wide array of distinctly uncommon - and what appeared to be innovative - organizational forms. Three main types can be discerned. A first type were international enterprises which emerged without a domestic base, with companies either registered in the home country but with no local operations, or with local operations but no sales, or even without any home operations or sales. These included free-standing companies, a term seldom heard in the IB literature but which can be regarded as born global 
companies 'avant la lettre', and companies created in host countries by expatriate entrepreneurs (Wilkins, 1988; Wilkins and Schröter, 1998; Jones, 2000; Lopes, 1997; Jones and Pitelis, 2015; Verbeke et al, 2014; Lopes et al, 2017). A second type of organizational form evolved out of collaborative arrangements, and was characterized by the absence of hierarchical relations between operations in different markets, and by limited equity stakes in foreign operations. This type has been described in the historical research on international cartels, some early forms of joint ventures, and so-called "cloaked" firms in Europe the interwar decades (Fear, 2008; Brown, 2000; Kobrak and Hansen, 2004; Kobrak and Wustenhagen, 2006; Jones and Lubinski, 2012). A third type of organizational form was a network of independent firms linked by equity and non-equity connections. These were akin to today's diversified business groups, but historically often originated from international trading companies. In these cases, enterprises tended to have a domestic base, even if only in services (Carlos and Nicholas, 1988; Jones, 2000; Jones and Khanna, 2006). Interestingly, this organizational diversity has returned in the recent past.

This research note addresses the following three issues. The first is to investigate the sources of the unconventional and innovative organizational forms of companies with multinational operations, drawing on historical evidence. The second is to propose an extension of internalization theory, taking into account the role of the entrepreneur in sourcing local knowledge in the host country, and the design of the headquarters, where the legal, financial and strategic roles of the MNE are supposed to be concentrated but whereby in some cases these roles became distributed across different markets. Rather than focussing on the familiar issue of the markethierarchy dichotomy, we show that firms did not necessarily change their entry mode when faced by market imperfections, but changed the design of their headquarters and the entrepreneurial type which acted as a vehicle to transfer or source knowledge. Third, the study examines the efficiency properties of the evolutionary paths chosen both in terms of who performed entrepreneurial roles and how headquarter roles were distributed.

The paper is organized in five parts. Section two provides an overview of the fundamentals of classic internalization theory, highlighting its implicit assumptions. It also explains how our empirical evidence might encourage an extension of mainstream theory, by adding two new dimensions: the role of the entrepreneur in sourcing local knowledge, and the design of the headquarters. Two main types of entrepreneurs are identified as providing knowledge: the innovative entrepreneur (from the MNE home country) and the local entrepreneur in the host country. The three main functions of headquarters that are central to its organizational design include the legal, financial, and strategic roles. Section three examines how entrepreneurs, and in particular expatriate entrepreneurs, impact on internalization decisions by MNEs. This section also discusses the nature of the opportunities they exploit and the modes of operation they employ in host countries. Section four provides historical evidence on how and why headquarters functions have been geographically distributed. It identifies the importance of political risk management and the seeking of efficiencies associated with access to resources and more 
favourable legal and fiscal environments as major motivations. Finally, the fifth section concludes and highlights how inductive historical research can help refine and extend current theories.

\section{Extending Internalization Theory}

\section{Theoretical background}

Classic internalization theory, first developed by Buckley and Casson (1976), and extended by Rugman (1981, 2005), Hennart (1982, 1991, 1993), Cassion (1987, 1990), Rugman and Verbeke (1992, 2003, 2008); Buckley and Casson (2009), Verbeke (2003, 2009), Narula and Verbeke (2015), and Casson et al (2016), amongst others, analyses the boundaries of firms in terms of market imperfections. Internalization occurs when the benefits of using hierarchy are equal or lower to the costs of using the market. The theory was originally developed as a general analysis of the boundaries of firms. However, the impetus for its development was the need to explain the post-1945 growth of market-seeking U.S. MNEs in knowledge-intensive manufacturing industries in Europe. This was undertaken by large U.S. corporations with multidivisional ( $\mathrm{M}$-form) organizational structures. The M-Form type of organization which developed from the 1920s, allowed firms to pursue strategies of diversification with a view to achieve efficiencies (Chandler, 1962; Chandler et al, 1997). As has been noted as far back as Casson $(1985,1986,1987)$, the fact that the classic internalization theory originated in particular historical circumstances created certain assumptions, and hindered application to understanding how international firms operated in different political and economic contexts.

Internalisation theory developed as an explanation of 'conventional' MNEs of the kind described above rather than as a theory of all MNEs. As a result, every time an 'unconventional MNE' was discovered, there was a call for a new theory. This has been the case with both emerging market MNEs and born global firms (Wells, 1983; Oviatt and McDougall, 1994; Knight and Cavusgil, 1996; Madsen and Servais, 1997; Cavusgil and Knight, 2015; Verbeke and Kano, 2015). Internalisation theory, as originally articulated, focused very sharply on issues of ownership and control, with higher risk being associated with organizational forms that involve higher control. It was assumed that other theories would be developed to address other key managerial issues. For example, the operations of host country licensees, franchisees and subcontractors would be explained by theories of small-firm behaviour, while the location of headquarters would be explained by organisational theory. These theoretical developments did not occur however, and so an obvious response is to extend the scope of internalisation theory to address these issues.

Rugman (1981) acknowledged the importance of entrepreneurial choices in the face of uncertainty and the impact of institutional variables, especially in the realm of distance among countries and regions. Rugman and Verbeke $(1992,2003)$ recognized a variety of strategic and managerial issues involved in internalization, focusing in particular on the management of the innovation processes. This is achieved by infusing a 'dynamic capabilities' like perspective, with an emphasis on 
generating, exploiting and rejuvenating firm-specific advantages and matching this with country specific advantages of host countries (Verbeke and Kano, 2012). Here we link internalisation issues to host country entrepreneurs and the sourcing of knowledge and the design and location of headquarters. Historical evidence (summarised below) suggests that these can affect internalisation decisions. Local entrepreneurs can play an active role in explaining internalization decisions and in the sourcing of local knowledge. In addition, the host country licensees, subcontractors, franchisees and sales agents, all of who can act as entrepreneurs, are not always local, and subcontractors and sales agents can be as entrepreneurial as licensees and franchisees.

In a similar vein, the classic internalization theory does not discuss the design of the headquarters. The theory expresses great confidence in the ability of the 'modern corporation', as described by Chandler, to internationalize without fundamentally changing its organisation or its operating methods (Chandler, 1962, 1977, 1990, 1991; Williamson, 1981a; Chandler et al, 1987). International diversification is supposed to respect the same organizing principles as domestic product diversification. In particular, internalization theory understates the importance of risk management, including political, social, business, financial, and natural risks (Casson and Lopes, 2013). While IB theory recognises these risks, they assume only a marginal role in the internalization theory, and at most they affect the mode of entry into a particular market (Hill et al, 1990; Agarwal et al, 1992; Buckley and Casson, 2009). Here we show that firms historically engaged in multinational activity do not automatically choose the entry mode that minimizes risk and maximizes control for the expected return. Instead, the number of internalization options becomes much wider, even within a single entry mode, when the impact of alternative designs of headquarters in the realm of internalization decisions is acknowledged, as well as the role of the entrepreneur in sourcing local knowledge.

In classic internalization theory, the legal, financial and strategic activities of the headquarters are all assumed to co-located, i.e. located in the same place. The headquarters are considered to readily manage operations from a distance, and efficiently control subsidiaries that may be operating in a more hostile environment overseas. Strategic knowledge is assumed to be generated in the headquarters, and local (and often also strategic) knowledge is supplied by the subsidiary. Communication with foreign subsidiaries is considered to be fast and to be easily effected, either remotely or face-to-face. Distance is a critical concept that affects the transferability, recombination, and exploitation of firm specific advantages across borders. If any dimension of distance increases, so do the costs of doing business abroad, as well as the challenges of effectively deploying firm specific advantages in a host environment. Distance creates new bounded rationality challenges for managers who must understand drastically different host environments, as well as bounded rationality problems (Wilkins, 2004; Verbeke and Greidanus, 2009).

All the assumptions from internalization theory have to be relaxed when using historical evidence on early MNEs. When internalization theory is stripped down to 
core principles, it becomes clear that the unconventional and apparently innovative organizational forms of early MNEs were an efficient response to the organisational problems of their time. Business history research provides a somewhat unique and complex picture compared to the IB literature dealing with the contemporary MNE, in particular, with regards to the role of the entrepreneur and the sourcing of local knowledge, and also the role of the headquarters. In international business history there is research, which emphasises global strategy, and other research which focuses on just a few markets. Some firms such as Ford, Singer, Siemens, J. \& P. Coats, Lever Brothers and Nestlé, as well as a multitude of trading companies and business groups, are present in multiple countries since early on in their activity (Wilkins, 1977, 1988, 2009, 2015; Wilkins and Hill, 1964/2011; Jones, 1988, 2005b, 2014; Jones and Schröter, 1993; Godley, 2006; Kim, 1995; Kininmonth, 2006; Lopes, 2010; Lopes and Casson, 2007, 2012, 2013). Other firms invested in just a few foreign countries, and many in just a single one. The individual host country can therefore occupy an important place in historical research. Other studies look the importance of MNEs and their impact (either positive or negative) on national economic development (Jones, 1987; Bostock and Jones, 1994; Jones and Bostock, 1996; Jones, 2013; Jones and Lluch, 2015; Barbero, 2015; Barbero and Lluch, 2015; Beatty, 2009; Piquet, 2004).

Business historians have also been interested not only in foreign direct investment (FDI) but in the transfer of technology and culture (Beatty, 2003), and for this reason they were concerned just as much about arm's length contractual arrangements such as licensing, franchising and subcontracting as they were about conventional FDI. Their research emphasises the important role of entrepreneurs, not only as managers of local subsidiaries, but as independent proprietors or as agents for foreign firms. The focus on host countries also means that business historians have been interested in local capabilities (Mason, 1992). Local entrepreneurship has long been seen as key to local economic development (Schumpeter, 1934; Knight, 1921; Kizner, 1973; Casson, 2003; Casson and Godley, 2005). Local entrepreneurs are very visible in historical business records. Limited liability joint stock companies were rare in the early and middle nineteenth century. The business partnership was still important, while the modern corporation was virtually unknown outside the railway industry. The role of the individual entrepreneur was therefore much more evident than it is today (Payne, 1974; Cottrell, 1979;Wilkins, 1988; 2009).

\section{Entrepreneurship patterns}

In the following sections we provide evidence on entrepreneurs operating in foreign markets and developing early forms of MNEs. It is possible to identify different types of entrepreneurs in terms of their involvement in multinational activity and also their type of career trajectories and background. The foreign firm would typically be founded by an innovative entrepreneur from the headquarters' country, while the business partner in the host economy would be a local entrepreneur. The innovative entrepreneur typically supplied knowledge regarding technology and product design as described by Schumpeter (1934), whilst the local entrepreneur contributed local knowledge, including insider knowledge obtained through personal networks, 
analogous to the Kirznerian entrepreneur (Kirzner, 1973, 1997). Early firms with multinational activity combined these two types of knowledge to serve their foreign markets through knowledge transfer between headquarters and subsidiaries. Their function was similar to what can be observed in the modern MNE, but the context was different, and this led to different organizational forms. The innovative entrepreneur would register the firm in the headquarters country, issue shares, and create a board of directors to represent the shareholders. A reputable non-executive chairman, typically drawn from the social elite, would be appointed. The entrepreneur would be a major shareholder and often act as managing director, overseeing the internationalisation process. On retirement he would endeavour to appoint his own successor who would carry on the entrepreneurial role (Jones, 2000; Garcia-Ruiz and Toninelli, 2010; Becker et al, 2011).

The local entrepreneurs could act in various capacities. They could own and control their own firm: a subcontractor would undertake local production while a franchisee would undertake local marketing. If both production and marketing were undertaken by the same local entrepreneur then the entrepreneur became, in effect, a licensee: they bought the right to produce and sell the product for a term of years at their own risk, subject to various restrictions on market area and pricing policy. As a subcontractor, a local firm could either add value to a product supplied to it by the foreign firm ('labour only subcontracting'), or supply a product it had produced entirely by itself (though perhaps using a foreign design). Franchisees typically owned the product that they sold, and therefore bore significant market risk; on the other hand, a sales agent would be rewarded with a fee. A franchisee would normally be tied in to purchasing from a specific foreign firm, although he might be allowed to handle non-competing franchises too. Agents might also be allowed to handle non-competing products (Becker, 1998; Jones, 2000; Lubinski and Jones, 2012; Jones and Colpan, 2016).

A local entrepreneur could act as the manager of a foreign subsidiary instead. In this role, he would exercise powers devolved from headquarters, and use his own judgement to implement the headquarters' strategy. In the nineteenth century communication was sufficiently slow, and risks sufficiently great, that local managers needed considerable autonomy to deal with unexpected threats or crises. The local manager would receive a salary, but could be rewarded with bonuses or increments if he performed particularly well. Nevertheless, many successful managers chose to leave their foreign employer once they had learned enough to set up a business on their own, becoming either independent partners of their previous employer, or in some cases rivals to this employer. Local entrepreneurs were not restricted to serve only the local market: they could export too, either to the source country, or to a third country, or to both. Exports to the source country were typically internal to the firm; the foreign subsidiary acted as an 'offshore' producer for the parent. Exports to a third country could also be internal, being consigned to another subsidiary of the same parent, as with trading firms; more commonly, though, exports would be supplied to independent foreign customers. In the nineteenth century, therefore, host-country entrepreneurs enjoyed considerable autonomy, whether as independent owners or as salaried employees (Becker, 1998; Jones, 2000). 
The nineteenth century and early twentieth century was a time of extensive international migration, especially from Europe to North America (Chiswick and Hatton, 2003). Migration is widely recognised as a selective process in which the young, healthy and most entrepreneurial from different social backgrounds are most likely to move (Hatton, 1998; Hatton and Williamson, 2002). Migration affected the supply of both innovative entrepreneurs from a home country and local entrepreneurs in host countries. The latter is the focus here. Migration is not necessarily a one-off process. Migrants may be itinerant, moving on to another country later, and perhaps eventually returning to their home country. Migrants intending to return may decide not to change their nationality, preferring to operate as aliens in the country where they work. Alien merchants are documented extensively in historical accounts (Jones, 2000; Chapman, 2003; McCabe et al, 2005; Casson and Casson, 2013). In colonies and dependencies, citizens of the colonial power often occupied a privileged position even though they were not native to the country. In India prior to independence, for example, Indian institutions often distinguished between British citizens, Europeans and other 'whites', Anglo-Indians of 'mixed race', and locals, with the natives being further classified according to religion, caste and ethnicity, such as Parsee or Marwari (Tomlinson, 1989).

In many colonies the resident expatriate was a familiar figure, a citizen of a foreign country but a permanent resident of the host country. While some expatriates settled permanently, often marrying locally, others were only temporary resident expatriates, as they returned home eventually (Lopes et al, 2017). The resident expatriates were well-suited to function as local entrepreneurs. They were familiar with the culture of their home country, and often had relatives there. They were also familiar with the host country, especially if they had in-laws there. They were 'boundary spanners', belonging to networks both at home and abroad. Some had a professional background and were affiliated with international associations too (e.g. consulting engineers). Another interesting group included the host-country locals from wealthy families who had been educated in the source country and returned to work at home. As alumni of elite educational institutions, they were 'trusted' (i.e., viewed as reliable) to manage foreign operations. Like resident expatriates, they did not only support foreign firms to operate locally, but also to help local firms obtain finance from the source country. Contacts with the source country in the financial sphere were particularly useful if they decided to set up their own local businesses financed from abroad (Oonk, 2007; Harlaftis and Minoglou, 2005; Jones, 2013; David and Westerhuis, 2014).

Finally, it is necessary to consider the temporary resident expatriate, who came from the source country specifically to be a local entrepreneur for a limited time. For the independent businessman, this implied a 'get rich quick' mentality, while for the manager of a foreign subsidiary it might involve a career move, designed to gain promotion. Young managers could be seconded for a short time from headquarters, and replaced by another secondee when they returned home. The relative benefits of locally-educated locals, foreign-educated locals, resident expatriates and secondees, it can be argued, depended mainly on the relative importance of the 
general knowledge possessed by the foreign headquarters and the local knowledge required for successful host-country operations. If local knowledge was the paramount requirement, then a locally-educated local entrepreneur who was totally embedded in the local community would be the right person for the job. At the other extreme, if up-to date familiarity with headquarters thinking was paramount, then the secondee was preferable. Although a steady stream of 'novice' secondees could prove disruptive, their up-to-date knowledge of headquarters thinking might outweigh this concern. Positioned closer to the middle of this spectrum of capabilities are the foreign-educated locals and the resident and temporary resident expatriates. Foreign-educated locals were more prominent in government and universities than in business, and so it is expatriates that are the focus in this paper. Expatriates were a compromise solution, combining an appreciation of headquarters culture and local culture (Jones and Wadhwani, 2007; Cassis and Minoglou, 2005; Godley, 2001).

\section{Design of headquarters}

We also identified historical patterns in terms of the design of headquarters by entrepreneurs with multinational activity. Business historians have been arguing for a while that the source country occupies a rather peculiar case in the business history literature because the location of the headquarters is sometimes unclear (Wilkins, 1988; Corley, 1994, 1998; Casson, 1994; Hennart, 1994; Hennart and Reddy, 1997; Wilkins and Schröter, 1998; Jones, 2000). Three main roles can be discerned. The first is that a headquarters represents the registered address of the firm for legal and tax purposes. This address governs where corporate taxes are paid, and therefore what rates of tax apply. In the nineteenth century, however, there were no significant corporate taxes, and as a result, off-shore tax havens were not the issue they would later become. As the location of the legal headquarters decides the judicial system used for the settlement of commercial disputes, this was very relevant to 'trader' MNEs making contracts with foreign businesses (Jones, 2000). The legal headquarters also gave the firm a right to call upon the home country government for protection of its overseas interests. When operating in a risky or politically unstable overseas environment, it was useful to have a major world power on the MNE's side: imperial capitals therefore attracted legal headquarters (Wilkins, 1999; Cassis, 2006).

Risk and political instability was important in other ways as well. When nations are at war, the legal headquarters may be moved to a safe haven, allowing the business to continue, even when the other headquarters functions are 'located' in an occupied country. If political instability is widespread, and even neutral countries are under threat, then multiple headquarters may be used: different holding companies of different nationalities are established, ready to be activated if and when required. Although legal headquarters may, in a physical assets sense, represent little more than 'brass name plates', deposit boxes, or empty rooms, they can be highly significant as risk management tools (Wubs, 2008). They can also be used for criminal purposes: for example, to disguise money transfers by drug traders and arms dealers (Austin et al, 2017). 
The second role of headquarters is that it represents the place where strategic decisions are taken by an innovative entrepreneur, and where the firm's board of directors convenes. In this context, 'strategic' means two things. First, that major investment decisions are being taken under uncertainty. These decisions are often irreversible, and resources, once committed to a project, cannot be easily recovered. A mining venture, for example, involves irreversible, fixed commitments to boring tunnels and building heavy transport infrastructure. If the project fails, a hole in the ground may be all that is left. On the other hand, the decision to build a new distribution centre may involve much less risk, because the warehouse and vehicles are versatile (or mobile) assets and can be easily sold off in the second-hand market if the project fails.

Strategic also means that interactions with other players are involved. These may be competitors, alliance partners, or the firm's own subsidiaries. The headquarters needs to monitor these players, predict their behaviour and plan responses to it, and where appropriate, negotiate with them. A headquarters that performs a strategic role requires access to highly skilled managers, supported by a range of specialised professionals. It may also benefit from being located close to the headquarters of its major partners and rivals, as well as its own subsidiaries, in order to have access to the best possible information (Marshall, 1920; Porter, 1998; Zeitlin, 2008).

Large-scale investments require finance, and this identifies the third role of headquarters. Three different forms of finance are normally involved: equity (the riskiest), long-term fixed interest debt (the second riskiest) and short-term lending secured on versatile collateral assets (the most secure form of debt from the lender's point of view). Procuring finance requires access to wealthy individuals and large financial institutions (notably banks). A stock exchange is required to provide liquidity to long-term investors. Financial backers making significant investments require regular face-to-face briefings. Thus the financial headquarters needs to be based in a major financial centre. There are a limited number of such centres from which to choose, which explains why so many large enterprises have financial headquarters in the same few locations (Wilkins, 1999; Cassis, 2006).

These three headquarters roles - legal, strategic and financial - are the most crucial. But it is worth noting another, namely the location of major research laboratories or other core management functions. While the research laboratory did not become a significant factor until the end of the nineteenth century, with the commercialisation of electricity, it is mentioned here for the sake of completeness. It has been suggested that the central laboratory needs to be co-located in the same country (even if not in the same site) as the headquarters, although with which type of headquarters is unclear (Dunning, 1998, 2009; Blanc and Sierra, 1999; Crisculo et al, 2005). It seems unlikely to be the legal headquarters, although co-location could be relevant if patents and other intellectual property are under threat. Co-location with shareholders also seems unlikely, because ordinary shareholders are unlikely to understand what is going inside in the laboratory, and it could undermine commercial secrecy if they did. The obvious candidate for co-location is the strategic 
headquarters, to allow the strategy of the firm to be aligned with new technologies and products emerging from the laboratory. Evidence suggests, however, that the strongest pull to attract laboratory locations comes from knowledge hubs, where pools of specialist researchers reside and university facilities are available to support research (Porter, 2000; Kristensen and Zeitlin, 2004; Benito, et al, 2009; Narula and Santangelo, 2012).

Focusing on the three main roles identified above, the question is whether these roles should all be co-located in a unitary headquarters. Classic expositions of internalization theory implicitly assume that they should (Buckley and Casson, 1976; Dunning and McQueen, 1981). The assumption is made by default, however, in the sense that the question is not really asked. Business history, on the other hand, clearly shows that it needs to be asked. Distributed headquarters, where different roles are carried out in different countries were very common in the nineteenth century and early twentieth century. There are two main reasons why headquarters roles could be distributed. One is specialisation of location according to comparative advantage, and the other is the management of risk. Comparative advantage implies that different headquarters roles require different sorts of inputs, and that different inputs are cheapest at different locations. Headquarters roles also require skilled professional workers and a sound institutional environment, whereby input costs are less important. Favourable access to legal skills could detach the legal headquarters from the others, and access to banking and financial institutions could do the same for financial headquarters (Wilkins, 1988).

Strategic decision taking could be detached in order to facilitate or accelerate flows of information and goods, in particular when communications were not fast. Risk management has been a very common cause of separation of headquarters roles. Co-location of headquarters' roles because of risk management, tends to be associated with cases of unfavourable tax regimes, war, expropriation, discrimination, and excessive or lack of regulation (Rugman, 1976; Morck and Yeung, 1991; Boddewyn and Brewer, 1994; Jensen, 2008). In the first case, it will be located in a tax haven, and in the other cases in a politically stable, well-regulated country. Since countries often become tax havens to compensate for other disadvantages (they are often small countries), a tax haven is unlikely to attract other roles. Hence, firms that relocate their legal headquarters for tax reasons, will usually have this legal headquarters separated from the strategic and financial headquarters - these other roles will not follow the legal headquarters to the same location. There are good grounds for co-locating the strategic and financial roles. Strategists will find it useful to sound out financiers on the prospects of funding major new investments. Bankers, entrepreneurs and wealthy investors constitute a social elite that will tend to have shared tastes, based around cultural and social activities, and value international logistics connectivity. They will therefore prefer to reside in the same sorts cosmopolitan locations. The main reason for pulling them apart is that the strategists may need to co-locate with operations, and operations may be based in an 'industrial heartland' elsewhere (Wilkins, 1988).

Finally, it should be noted that headquarters' roles can sometimes be replicated in different locations. A focus on risk management would suggest that in times of war, 
the legal headquarters could be replicated among several locations. If there are two belligerent countries, and a neutral country, which might also be invaded, then it could pay a vulnerable MNE to have headquarters in each, so that irrespective of whom won the war, the firm would command headquarters in the 'winning' country, whether or not the neutral country were invaded (Wubs, 2008). Financial headquarters can also be replicated, but for different reasons. If two large firms merge to create an even larger firm, the new firm may acquire two large pools of shareholders in different financial centres. To keep the loyalty of both groups, it may decide to retain a presence in both countries by maintaining a headquarters office there (Wilson, 1954, 1968; Jones, 2005b; Jonker and van Zanden, 2007). Note that while different legal locations are normally alternatives to each other, different financial headquarters may be complements instead. In certain circumstances, however, legal headquarters could be complementary too, e.g., if the MNE has foreign investments in two different empires, or spheres of political influence, it might maximise its political leverage by headquartering different holding companies in each imperial capital (Jones, 1981, 2005).

\section{Proposed extension}

IB theory has dealt with these topics separately. On the one hand, it has discussed the role of the entrepreneur in the sourcing of knowledge and the accessing of complementary assets (Richardson 1972; Rugman, 1981; Teece, 1986; Verbeke et al, 2014; Verbeke and Kano, 2015). On the other hand, it has studied the design and functions of the headquarters (Hedlund, 1986, 1994; Bartlett and Ghoshal, 1989; Ghoshal and Bartlett, 1990; Young and Goold, 1999; Sölvell and Zander, 1995; Foss, 1997; Collis et al, 2007; Andersson and, 2010; Hilleman and Verbeke, 2014; Kunisch et al, 2015; Coeurderoy and Verbeke, 2016; Meyer and Benito, 2016). The historical evidence presented here challenges us to assess whether analysis of entrepreneurial roles and headquarters role distribution can be combined with internalization theory to explain unconventional or innovative organizational forms of MNEs. Figure I illustrates such approach. 
Figure 1 - Proposing an Extension of Internalization Theory

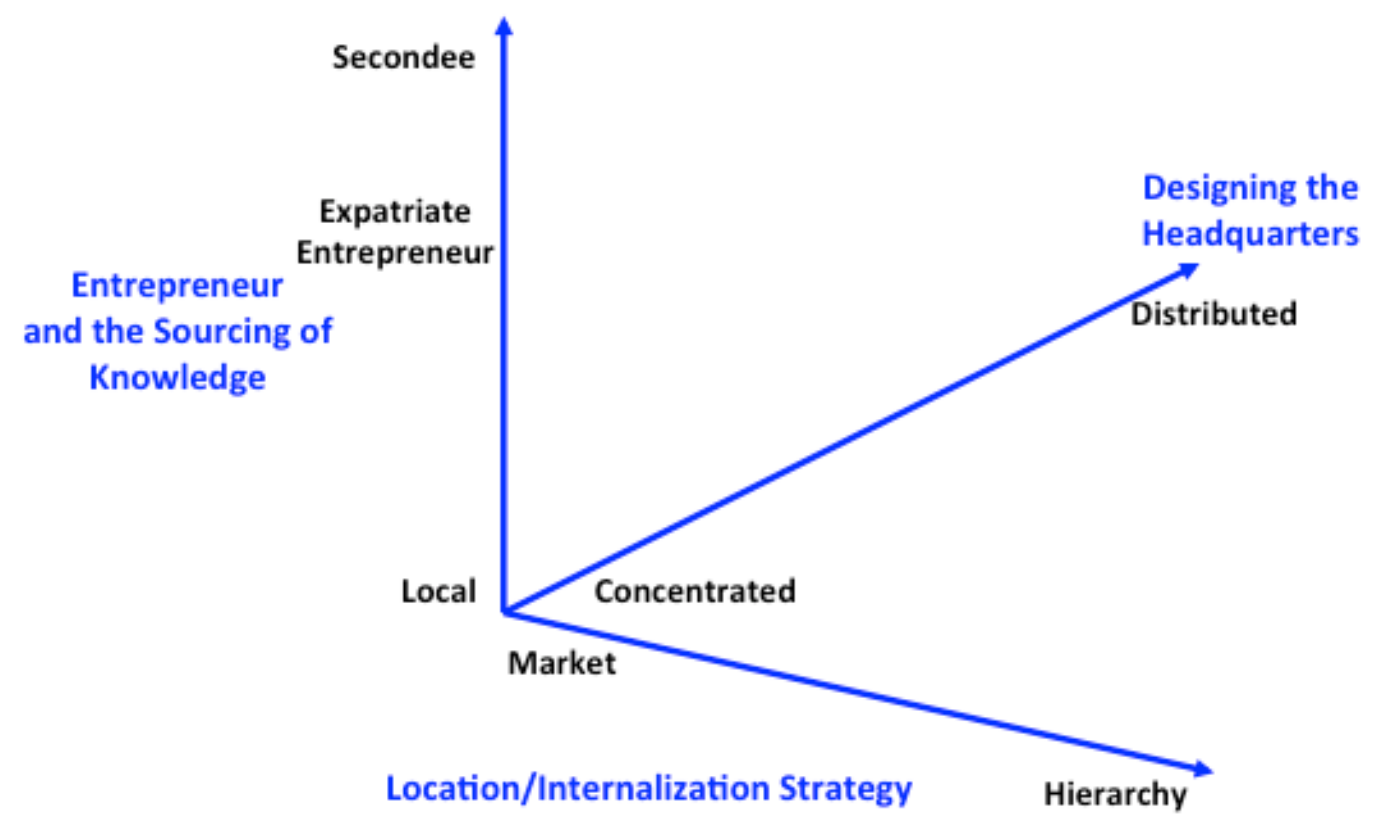

Source: Authors

There are three dimensions, each one represented in a separate axis. On the first dimension, the innovative entrepreneur chooses the location and internalization strategy of the corporation, which ranges from markets to hierarchies, and includes other hybrid modes such as subcontracting, franchising, and licensing. The second dimension relates to the type of entrepreneur chosen for sourcing of local knowledge in the host country. It can be a local entrepreneur, an expatriate entrepreneur or a secondee sent from the home country. The type of expatriate could include an alien migrant, permanent resident expatriate or a temporary resident expatriate, among other options. On a third dimension, the innovative entrepreneur chooses the design of the headquarters, which can range from colocating all the headquarters functions (legal, financial and strategic) in one country, to distributing these across distinct markets. Other options exist in between these two extremes. For example, the legal and financial functions could be concentrated in one country, with only the strategic function distributed. The historical evidence collected to develop this proposed extension of internalization theory is provided below, in sections 3 and 4 .

It is possible to find patterns and interdependencies between internalization strategies, the innovative organizational forms chosen by firms, and also the geographical distribution of headquarters roles. Firms that rely on expatriate entrepreneurs tend to have both the advantages of knowledge transfer and sourcing of local knowledge, with the inherent limitations associated with bounded rationality (Williamson, 1975; 1981a, 1981b, 1996). Firms operating in distant and less developed markets, looking to funding their activities, tend to create headquarters with financial detachment so that they can access more advanced and efficient capital markets. Firms striving to survive in markets characterized by high risks, tend 
to choose legal detachment. These risks can be varied, and include legal (eg. taxation), political (eg. war) and economic and business (eg. lack of protection of intellectual property rights). The strategic detachment of headquarters tends to occur when it is not possible to manage operations from the legal headquarters because of difficulty of communications, especially the time to take strategic decisions in very short periods of time. It is also possible to identify 'clusters' of behaviour of MNES, where they share similar preferences with regards their decisions to internalize, choose entrepreneurs to manage their business in the host country and design the headquarters. Co-located MNEs are more likely to internationalize and create subsidiaries in foreign markets, either by sending secondees, or hiring local managers. Firms operating in high-risk environments are more likely to detach the legal headquarters. Firms investing in very different cultural and institutional environments, with a strong need to take decisions and adapt their strategies and operations to local environments are more likely to detach their strategic activities and use expatriate entrepreneurs to manage their businesses (Gálvez-Muñoz and Jones, 2001).

\section{The Entrepreneur in the host country}

Expatriate entrepreneurs are well-equipped by life experience to manage effectively in culturally diverse settings, and to network internationally (Lopes et al, 2017). In the nineteenth century many entrepreneurs were attracted to high-risk environments, such as the American frontier, gold rushes, and diamond rushes. Their lifestyle often involved significant mobility between employments as well as between countries (McCraw, 1995; Casson and Casson, 2013). Some expatriates such as Andrew Carnegie who immigrated from Scotland to the US in 1848, did not have any technical training (Livesay, 1975; Chandler, 1977). Others, were educated, with a professional background by the time they started their new businesses in foreign countries. Hans Wilsdorf, the creator of the famous (and eventually Swiss) watch Rolex, was born in Germany and moved to Geneva after loosing his parents and finishing high school. First he worked for a pearl trading company, and then for a watch exporter Cuno Korten. When he was 22, Wilsdorf moved to London first to work for a watch making company; and set up his own watch making business in 1908. During World War I he moved his business to Switzerland due to watime tax increases in Britain in levied on luxury imports. In 1920 he acquired Aegler, his wristwatch movements supplier in Switzerland, and moved the headquarters of the firm to Bienne (Jones and Atzgerger, 2015; Jones and Pitelis, 2015). All the previous experience gave Wilsdorf the technical skills to manage more risky projects and the social confidence and networks to raise funds to finance them.

Notwithstanding this, in countries with large expatriate communities they could be cliquish; trust between expatriates was often mediated by peer-group monitoring through membership of 'the club'. In some countries, in particular colonies or developing countries, the membership of elite clubs provided entrepreneurs with the possibility to network informally and also discuss business. But it was also common for entrepreneurs to create linkages between each other through 
interlocking directorships in their respective organizations (Ridings, 1985; Cage, 1985; Cassis, 1992; Landes et al, 2010; David and Westerhuis, 2014).

As highlighted in Figure 1 above, host country expatriates could engage in international operations in three main ways. First, they could act as subsidiary managers. Such managers were often recruited from extended families, networks of friends, or through the wider expatriate community in the host country (Wilkins, 1988; Jones, 1986, 2000, 2005). Second, they could operate as subcontractors, franchisees, licensees or agents. In some cases they acted as local representatives of trading companies, which were conspicuous in exports of commodities. In other cases they handled the sale of patented machinery or branded consumer products. They were not always reliable partners, however. They could copy and improve technologies used under licence, imitate or counterfeit franchised brands, and infringe agreements by exporting outside their designated market areas. While they were often selected as business partners because they were believed to be more 'trustworthy' than fully local people, this advantage was relative rather than absolute (Wilkins, 1988).

Third, expatriates could set up their firms, either by going solo or in partnership with others. In some cases they would travel back to their home country to raise finance before returning to the host country to invest in the business. Quite large businesses could be established in this way, including mines, ranches, commercial forests and even the railways that conveyed commodity exports to the nearest port. Expatriates also contributed to building urban infrastructure, including roads, utilities, and large-scale housing developments. Many of the larger companies established in this way were 'free-standing'; they were legally headquartered in, and financed from, the expatriate's home country, as described in section 4. Strategy was often devolved to the host country, especially before circa 1890 . They typically followed a pattern where legal and financial headquarters were in the entrepreneur's home country and strategic headquarters in the host country (Hennart, 1986; Wilkins, 1988; Wilkins and Schröter, 1998; Cassis, 1992; Jones, 1993, 1998, 2000; Lopes and Simões, 2017).

Table 1 identifies four different types of activities that commonly appear carried out by expatriate entrepreneurs in IB history. Each type of activity combines specific economic functions associated with different market opportunities. The types of activities are indicated in the columns and the opportunities identified by the expatriate entrepreneur in the rows. Each type of activity is discussed in turn. The crosses identify the cases where evidence was found, i.e. market opportunities that led expatriate entrepreneurs to be involved in specific types of activities in foreign markets. 
Table 1 - A typology of roles commonly performed by expatriate entrepreneurs in the host country

\begin{tabular}{|l|c|c|c|c|}
\hline \multicolumn{1}{|c|}{ Activity } & $\begin{array}{c}\text { Import/export } \\
\text { merchant }\end{array}$ & $\begin{array}{c}\text { Subcontractor/ } \\
\text { associate producer } \\
\text { for foreign firm }\end{array}$ & $\begin{array}{c}\text { Franchisee of foreign } \\
\text { firm }\end{array}$ & $\begin{array}{c}\text { Licensee of foreign } \\
\text { firm }\end{array}$ \\
\hline $\begin{array}{l}\text { Local market recognition for } \\
\text { local production or import }\end{array}$ & $\mathrm{X}$ & $\mathrm{X}$ & $\mathrm{X}$ \\
\hline $\begin{array}{l}\text { Local production site } \\
\text { recognition for local } \\
\text { consumption or export }\end{array}$ & $\mathrm{X}$ & $\mathrm{X}$ & $\mathrm{X}$ \\
\hline $\begin{array}{l}\text { Local adaptation of foreign } \\
\text { technology }\end{array}$ & $\mathrm{X}$ & $\mathrm{X}$ & $\mathrm{X}$ \\
\hline $\begin{array}{l}\text { Local adaptation of foreign } \\
\text { brand }\end{array}$ & & $\mathrm{X}$ & $\mathrm{X}$ & $\mathrm{X}$ \\
\hline Access to foreign risk capital & & $\mathrm{X}$ & $\mathrm{X}$ \\
\hline Access to local risk capital & & & & \\
\hline Source: Authors & & & & \\
\hline
\end{tabular}

The activity of the import/export merchant (column 1) is associated with the identification by the entrepreneur of local market opportunities for local production, for import, for local consumption or for export, and is often associated with access to local risk capital. An example is Joseph Nathan, a Londoner who settled in Wellington, New Zealand in 1857 and established the firm Joseph Nathan \& Co. He began by importing groceries, ironmongery, from Great Britain. The fact that New Zealand was part of the British Empire facilitated the trade of goods between the two markets, with almost no barriers to entry. In the 1890s, with the development of both refrigerated ships and New Zealand farmers' selling cooperatives, he began exporting frozen meat and butter to Britain. His business prospered, and by the 1930s the company, which had by them expanded into dried milk, detected an unexploited opportunity in nutritional foods, this marking the beginning of diversification into pharmaceuticals with the production of vitamins. This company developed into Glaxo, a major manufacturer of pharmaceuticals, which subsequently, in 2000, merged with Smith Kline Beecham to form pne of the largest pharmaceutical companies in the world - MNE GSK (Davenport-Hines, 1986; Davenport-Hines and Slinn, 1992).

An illustration of the case of associate producer (in column 2 in Table 1) is the firm Sandeman \& Co. set up in Porto, Portugal in 1814 by George Sandeman. George Sandeman was a partner of a British firm Sademan Gooden \& Foster, set up in 1790 dedicated to the import and export of wines, as well as British linens, cotton goods and other manufactured products. The business sold port wines, among other alcoholic beverages, the firm had exclusive rights to the distribution and sale for the port wine Campion, Offley and Hesketh \& Co, Warre \& Co., and also Thomas da Rocha Pinto in the British market, based in Portugal. Even though intermediation commissions were good, Sandeman considered that the considerable margins obtained by wine producers were very attractive. That knowledge, and also the 
development of new networks with farmers and other wine producers over the years, and also the increase in demand for port in the UK as the result of the Napoleonic Wars which stop imports from France, created opportunities for new port businesses to develop. In 1814 George Sandeman decided to set up his own port wine firm in Porto, independent of his London partners. The company was registered in Portugal and was completely independent from the UK business. This led to a sharp decline in business for the port firms Sandeman used to act as an agent for in the UK. To develop the business George Sandeman sent his nephew George Glas Sandeman to manage the newly established firm. From then onwards the British firm Sandeman, Gooden \& Foster (SGF) essentially purchased, blended, aged and sold port wine which was supplied by Sandeman \& Co. While acting at the main distribution channel in the UK, SGF was also central in the financing the Portuguese firm through loans (Halley, 1990; Duguid and Lopes, 1999).

A notable example of franchising (column 3 in Table 1 ) is the sewing machine company Singer, usually considered to be the first firm to use such mode of entry in different markets. In the US, Singer used a network of licensed engineers across the country, who would carry stocks of the most common components and repair the machines locally. The engineers were all self employed and paid directly by the customer, but could call themselves 'official licensed repairers'. The engineers would buy component stock from Singer and also pay Singer a small percentage of the invoice price as a fee for being allowed to operate as authorized repairers. The business developed to the point where repair engineers also sold replacement machines. In foreign markets, Singer used franchising to enter markets that were not considered to be strategic. For instance, in 1872, Singer established a contract with Bassett \& Company to develop secondary markets. Bassett handled Singer machines in Chile and Peru and appointed sub-agents in other South American countries. The contract required it to maintain 'suitable stores' in Valparaiso and Lima 'for the exclusive exhibition and sale' of singer sewing machines, 'to appoint and maintain agencies' throughout Chile and Peru, to maintain an inventory adequate to serve the trade, to extend the usual terms of create and to set retail prices approved by the Singer company. Bassett had, however, to rely on its own resources to finance the marketing effort. These franchising agreements provided a mode of entry with limited risk into these markets and simultaneously formed the learning platform for subsequent foreign direct investment from 1883, when Frederick Bourne became president of the firm and exclusive sales organizations were established in the regions where the company had already expanded (Davies, 1969, 1976; Carstensen, 1984; Cruz-Fernández, 2014).

Licensing agreements (column 4 in Figure 1) generally require partners with more technical expertise than merchants or franchisees because they need to absorb technology in order to produce the product that they sell. An illustration is the contract set up by the Berliner Company from the US with Trevor Williams, a British solicitor, to act as exclusive sales agent and licensee in the import of records from the US, and also to produce them. To develop this business Trevor Williams set up the Gramophone Company 1898. In 1899 the company purchased the rights from Eldridge Johnson, a New Jersey engineer who had developed a spring motor that 
operated recordings quietly at a uniform speed, to manufacture sound recordings. In 1901, Johnson agreed with the British licensee that they were guaranteed at least 50 percent of Johnson's present and future capacity. The world's markets were divided. The Gramophone Company was to sell in Europe, the British Empire, Russia and Japan, and Johnson everywhere else. Although the company was of British origin, with capital raised in Britain, its technology and senior management were American The rationale for the choice of licensing agreements as opposed to other modes of entry was the desire to jump tariffs, the nature of the product and the market, enabling, for example, the firm to reduce the delays in bringing out new lists of locally recorded music; and transport costs (Jones, 1985).

Expatriates were not, of course, the only people managing international operations in host countries. The policy of seconding headquarters staff to manage overseas subsidiaries became common in the early twentieth-century. The British cotton thread MNE J. \& P. Coats was pioneering in the industry and one of the biggest MNEs before 1914, traditionally relied on agents to sell in foreign markets. From 1889, after the appointment of a new foreign sales manager Otto Ernst Philippi, the company changed its market entry strategy in foreign markets by creating 'The Central Agency' which aimed to control all the sales in foreign markets, except the US where alternative arrangements were in place. J. \& P. Coats organization structure in international markets became very complex, with a large number of foreign subsidiaries with various degrees of ownership. Entry in foreign markets was essentially through mergers and acquisitions. That mode of entry was the most efficient in a market characterized by increased tariffs and increased competition. The combination of these factors meant that it was more effective to produce locally than to export (Wilkins, 1989; Kim, 1995, 1997; Kininmonth, 2006). Throughout the twentieth century professional management and the assignment of managers to overseas posts was to become the hallmark of US FDI. The secondment of staff to subsidiaries replaced reliance on resident expatriates. In most cases, seconding staff to foreign markets proved to be effective. They had the knowledge of how to manage the company (Wilkins and Hill, 1964/2011; Wilkins, 1970, 1974, 1989, 2004).

\section{The Design of Headquarters}

We presented case study evidence that was used to identify patterns of design headquarters and to propose an extension to the internalization theory in section 2 . Table 2 suggests the typology of headquarters designs based on the level of centralization versus geographic distribution of the different headquarters functions - legal, financial and strategic. The letters $(A, B, C)$ identify the country where the headquarters is located ( $A$ represents a first source country, typically - though not necessarily - the home country; $B$ represents another country; and $C$ represents a third country). There are five logical possibilities that need to be considered for headquarters' design strategies. Each involves a different pattern of location. The first is conventional co-location, shown as 'Pattern 1 ', where all roles are located in the same place. The next three columns indicate different forms of separation of headquarters roles: legal detachment, where the legal headquarters is moved to country B, financial detachment, and strategic detachment. The final column 
indicates a fully distributed headquarters where each role is performed in a different location from the other ones.

Table 2. Five patterns of Headquarters Design Strategy

\begin{tabular}{|l|c|c|c|c|c|}
\hline & \multicolumn{5}{|c|}{ Location strategy } \\
\cline { 2 - 6 } & Pattern 1 & Pattern 2 & Pattern 3 & Pattern 4 & Pattern 5 \\
\hline $\begin{array}{l}\text { Headquarters } \\
\text { role }\end{array}$ & Co-location & $\begin{array}{c}\text { Legal } \\
\text { detachment }\end{array}$ & $\begin{array}{c}\text { Financial } \\
\text { detachment }\end{array}$ & $\begin{array}{c}\text { Strategic } \\
\text { detachment }\end{array}$ & Distributed \\
\hline Legal & A & B & A & A & A \\
\hline Financial & A & A & B & A & B \\
\hline Strategic & A & A & A & B & C \\
\hline
\end{tabular}

Source: Authors

Note: $A, B, C$ - different countries for headquarters roles

The conventional arrangement (Pattern 1 in Table 2 ) is the one typically assumed for a MNE. An illustration of legal detachment (Pattern 2 in Table 2) is the Swiss MNE Nestlé just before World War II. In response to mounting international tensions, the company decided to restructure as a precaution. This restructuring stripped the headquarters of direct management of most of its established markets. Two legal headquarters were created with the aim of securing the survival of the company's business in the Americas should a war brake out and Switzerland either entered it or was overrun. The parent company was transformed into a holding company - AngloSwiss Holding Company and remained based in Switzerland, the same country as the financial headquarters. Nonetheless, a second holding company - Unilac, was created by a number of Nestlé overseas associates. Unilac's legal headquarters were in the Republic of Panama, where Nestlé had been present for many years, and remained so until 1985. When World War II became imminent it was decided that the top senior executives of Nestle would be split. The Chairman, Edouard Mullet, the Chairman, moved to Stamford, Connecticut, and devoted himself to run the overseas side of the business including North, Central and South America, and Britain (and Britain controlled the activities in Asia, including Japan). It was becoming easier to supervise some of the distant markets from the US than from Switzerland. This move switched the firm from pattern 2 to pattern 5 in Table 2, where all the headquarters role appear disintegrated. The Vice-Chairman, Carl J. Abegg, and the Managing Director, Maurice Paternot, remained in Switzerland and dealt with the continental European markets. These moves, which divided the company's interests into two groups, each falling into the logical sphere of influence of one or other two jointly-owned holding companies, greatly simplified that task of management under exceptional war conditions (Heer, 1966, 1991; Kurosawa, 2010; Donzé and Kurosawa, 2013).

Another example of legal detachment (pattern 2 in Table 2) is the case of the German pharmaceutical company Beiersdorf. In order to limit the risk of expropriation should another war break out, in 1934 it created an international 'ring structure'. This structure placed the subsidiary in Amsterdam in the middle of a ring of foreign affiliates. As a result of this re-organization the core company in 
Amsterdam (which had been until then a subsidiary of Beiersdorf in Germany) became responsible for purchasing the most important raw materials and ensuring quality control, for jointly-organizing research, advertising and general administration. This central organization was financed by an annual fee to be paid by the other ring firms. In most countries, such as Switzerland, France, and the US, Beiersdorf's affiliates held only the trademarks and sometimes plants and equipment, whereas the actual business was done by independent partner companies. The profit was divided evenly between the Beiersdorf affiliates and the partner firms in the respective markets. The parent company in Germany received a license fee based on turnover. The contact to Beiersdorf Germany was limited to the fee and the purchase of those raw materials and products that could not be manufactured abroad. As a consequence, Beiersdorf was henceforth composed of two legally separated pillars, the German business and the foreign business (Jones and Lubinski, 2012).

An example of financial detachment (Pattern 3 in Table 2) is Jardine Matheson, which was first established in 1832, in Canton (now Guangzhou) by two British expatriate entrepreneurs, and was known for its leading role in the opium trade, as well as trading tea and cotton. This firm was established in the first place to take advantage of the opportunities created by the end of the monopoly of the British East India Company on trade between Britain and China. While the main shareholders were based in the UK where it was easier and more effective to fund new investments, and also where they recruited their staff and sold their tea, the legal headquarters and strategic headquarters were both located in China. William Jardine, a British citizen, moved to Canton, where he lived as an expatriate entrepreneur until he retired in the UK in 1837. In 1841, he was elected a Member of Parliament. James Matheson also returned to the UK in the early 1840s, and also became a Member of Parliament, among other duties that he took upon his return such as serving as chairman of the Peninsular and Oriental Steam Navigation Company. In 1842 the legal headquarters moved to Hong Kong, which has been ceded to Britain as a result of the First Opium War and the Treaty of Nanking. The Jardine Matheson group still exists today as a diversified business group with businesses spreading from retail, to real estate, financial services, shipping and aviation, and hotels, among others. In 1984, following the agreement of the British government of Margaret Thatcher to transfer sovereignty of Hong Kong to China in 1997, the legal headquarters were moved to Bermuda, with the main shareholders remaining in Hong Kong, and the top management based in the United Kingdom. Jardine \& Matheson had its business in China expropriated in 1947, so this move aimed to prevent any possible risks that might arise once Hong Kong became part of China. The move of the legal headquarters was followed by a move of the financial headquarters with the primary stock exchange moving to London in 1994. Nonetheless Singapore becoming the primary trading market. The more recent changes in the location and functions of headquarters positions the firm today as reflecting pattern 5 in Table 2: the location of the legal headquarters is different from that of the financial headquarters and both are distinct from the location of the strategic headquarters (Jones, 2000; The Economist, 2015). 
Another illustration of pattern 3 in Table 2 is the Precious Metals Corporation set up in South Africa in 1949 by the American entrepreneur Charles Engelhard Jr. While the main shareholders, such as Robert Fleming \& Co, a London merchant bank, were based in the US and Great Britain, the legal headquarters and top management were based in South Africa. This investment resulted from an opportunity, identified by Engelhard when travelling in South Africa, to manufacture gold products for sale in the Far East where people prefer gold to paper money (Bedingfield, 1963; Jones and Benton, 2016). The main rationale for the choice of such design of headquarters very similar to that of Jardine's over a century earlier, related to the ability to source the investment more sophisticated capital market.

Strategic detachment (Pattern 4 in Table 2) is illustrated by the free-standing firm, a type of firm identified by Wilkins (1988) which was 'the most typical; mode of British direct investment before 1914'. Other countries, also developed free-standing companies but their contribution to world trade and investment during the same period was much less significant (Corley 1994; Wilkins and Schröter, 1998). These firms did not grow out of the domestic operations of existing enterprises as US MNES did for the same period. In most cases they were set up by expatriate entrepreneurs who, aimed to tap into the British capital market, and established legal headquarters in the home country, but conducted all their activities in the host countries that offered attractive opportunities. This type of firms gave the borrowers privileged access to capital and protected the firms by British law, while tapping into overseas opportunities. The home country offices normally comprised a corporate secretary and the board of directors, and little else. This type of firms was particularly important in industries such as transport infrastructure, utilities, primary-sector; and urban development (hotels, offices, housing and so on). Several efficiency arguments have been provided ranging from the internalization of capital (Hennart, 1994) as borrowers had privileged access to capital. It also provided them with the ability to internalize competitive advantages associated with the market for project management skills (Casson, 1994), as manufacturing investments did not tend to take this form. An illustration is the Anglo-Persian Oil Company, set up in the United Kingdom in 1908. The venture had originated as an endeavour to find oil in Iran on the basis of a wide-ranging concession granted to William Know D'Arcy, an Australian mining entrepreneur. The venture had been struggling, and only survived after the British government - anxious to achieve a supply of oil - persuaded an existing company, Burmah Oil, to invest equity. In 1909, following the discovery of oil, the Anglo-Persian Oil Company was founded as a free-standing company. The Legal headquarters, as well as the board of directors were in London. But all the strategic decision taking and operations were based in Iran. It remained in this structure until 1914, when the British government took a majority shareholding, and subsequently transferred expropriated German owned distribution and transport companies in Britain to Angle-Persian (Jones, 1981; Corley, 1983; Ferrier, 1982).

Another example of pattern 4 in Table 2 was Adidas, the manufacturer of sportwear. This family firm was established in 1920 for the production of sports shoes. In 1959, the son of the owner, Horst Dassler, was sent to Landersheim in France to create an Adidas subsidiary. After the death of his father Adolf Dassler, Horst Dassler became 
the top manager of Adidas but chose to stay mainly in France, rather than return to Germany where the headquarters were incorporated. Managing the company from France allowed Horst Dassler to strengthen the company's position in that market. Among other strategic initiatives, he bought Arena and Le Coq Sportif during the 1970s, which he kept off the Adidas books. Throughout his life he managed Adidas operations worldwide from France, even though its legal and financial headquarters, were in Germany. While there was a governance efficiency rationale was associated with the need for the CEO of the company to be near the market where the company was aiming to invest at the time, the main reason was to separate the strategic decision taking from the majority control and opinion by the family, a reflection of the dysfunctional nature of the Dassler family (Jones, et al. 2016; Simson and Jennings, 1992: 24-25).

The case of distributed headquarters (pattern 5 in Table 2) is illustrated by Companhia Real dos Caminhos de Ferro Portugueses, established in Portugal in 1859. It is the result of foreign investment in Portugal by a group of investors from France, Spain and Portugal. French institutions had the majority of the shares and control of decision taking. Even though the bylaws envisaged that the board of directors in Portugal should be the only official top management body, in practice the 'delegation in Paris' had the actual role of managing the business. The Paris Committee was comprised of a large number of top managers, which included a chairman of the board in Paris, one executive director, an engineering consultant, and various members of staff involved in financial and cost accounting, equity and debt management. The Paris Committee approved all new contracts, issued new bonds, established new business alliances and provided loans to other companies, hired new engineering consultants and executives, and purchased new rolling stock and material, without consulting the board in Lisbon. In contrast, the formal board in Lisbon had a smaller staff and merely operational and administrative duties. Thus, while the legal headquarters were in Portugal, the strategy was set up in France, and some of the major shareholders were in Spain. This form of governance remained in place until 1884 when, as a result of negotiations with the Portuguese government for a concession for a new line, the Portuguese parliament approved an additional clause stating that Portuguese citizens should occupy the majority of seats on the board of directors. By 1887 the bylaws review had removed all powers assigned to the Paris committee and shifted managerial control to the Board in Lisbon. This led Paris to appoint a General Inspector of operations in Lisbon to oversee operations. The off-shoring of management activities in France, with the majority shareholders in Spain and the legal headquarters in Portugal, was a way to access management skills vital to railway construction and operation not available on site in Portugal (Silva, 2014).

From the historical examples provided above for alternatives of organizational designs of headquarters, one can see that, on the one hand, legal headquarters tend to be detached when investments take place in high-risk markets and firms need to safeguard their survival. On the other hand, financial detachment is explained by the need for entrepreneurs to internalize capital markets. Finally strategic detachment tends to take place when it improves the efficiencies in terms of flows of goods and 
knowledge. Firms often tend to choose markets where they can be embedded in networks and value chains that are strategic for the activities of firms. In most cases, it is efficiency considerations that dictate the particular geographic distribution of headquarter roles. However, in some circumstances that is not the case. As discussed by Cyert and March (1963), Aharoni (1966), Boddewyn (1983), Aharoni et al (2011), and Vahlne and Johanson (2014), among others, foreign investment decisions are a complicated social process. Organizational behaviour, and personal preferences of entrepreneurs and other behavioral variables, such as social networks, can also be alternative rationales for internationalization.

\section{Conclusion}

This research note has explored how historical evidence can challenge a common misperception about internalization theory. International business history provides many rich and informative examples of firms that appear to have adopted organizational forms viewed as innovative and unconventional today, but that were quite common in earlier historical eras. Entrepreneurs, in most cases, acted quite rationally at the time that they operated, aiming to maximize efficiencies such as those associated with access to more efficient capital markets and safer institutional legal systems, and the ability to take timely decisions adapted to local environments. Entrepreneurs also aimed to minimize risks and maximize the chances of growth and survival of their business. Some of these firms with unconventional organizational forms and multinational activity evolved into modern MNEs by adapting their organizational strategies and structures to changing circumstances, while other ones did not survive or were merged or acquired.

The modern MNE did not develop down a linear path from a smaller and simpler version of itself. When confronted with new or unexpected imperfections in markets, the MNE does not necessarily change the mode of entry from markets (or hybrid modes such as joint ventures) to hierarchies, or from hierarchies to markets (or to any hybrid mode). Instead, the MNE can choose to keep the same mode of entry and either change the design of its headquarters by distributing all or part of the headquarters functions (legal, financial or strategic) across different markets, or can change the type and role of the entrepreneur used to provide or source local knowledge in the host country (from a local manager, to an expatriate entrepreneur or a 'secondee'). In some cases, the MNE changes both the design of the headquarters and the type of entrepreneur sourcing local knowledge.

Nineteenth-century MNEs had to address problems of slow communications and high risk. They needed to devolve power to foreign subsidiaries or affiliated firms, which could then respond to local problems in a more timely fashion, using local knowledge. For this purpose, they needed local entrepreneurs, and expatriates were considered very suitable. The flexibility of early MNEs was achieved partly by adopting what would be called today a 'network structure' or 'heterarchy', in which headquarters confined themselves to legal or financial roles, and gave subsidiaries considerable strategic autonomy. 
It looks likely that some of these apparently innovative and unconventional, but highly flexible organizational forms may re-emerge in the twenty-first century as a response to increasing and different types of risks - legal (eg. taxation), political (eg. war, terrorism, nationalism, and populism), and economic and business risks (eg. trade protectionism and weak protection of intellectual property rights), and climatic (eg. floods and tornados). While local entrepreneurship provides flexibility in the host country, it is likely that corporate headquarters will need to become more flexible too. 'Unbundling' or distributing headquarters activities is already quite common. It often carries negative connotations in popular discourse, e.g., the phenomena of offshore tax havens and the concentration of financial capital in 'global cities'. However, there is a positive side to headquarters activity unbundling. Business history analysis of these risks, and more broadly, of elements of institutional quality, are critical to explaining MNE choices of entrepreneurial roles in the host country and the distribution of headquarter roles.

The proposed extension to internalization theory takes into account different imperfections in markets, but considers a variety of strategic and managerial issues. It supports, therefore, Verbeke and Kano's (2015) argument that internalization theory can be enriched through "the infusion of a substantial business history perspective." However, while proposed extensions have tended to focus on the management of the innovation process (Rugman et al, 2011; Verbeke, 2009; Verbeke and Kano, 2012), here we propose that internalization theory needs to take into account different configurations of particular entrepreneurial roles in foreign operations, and also organizational designs and distribution of headquarters' roles. These patterns emerge clearly from deep engagement with historical evidence.

\section{References}

Agarwal, S., and Ramaswami, S. N. 1992. Choice of Foreign Market Entry Mode: Impact of Ownership, Location and Internalization Factors. Journal of International Business Studies, 23(1): 1-27.

Aharoni, Y. 1966. The foreign investment decision process. Boston: Harvard Graduate School of Business Administration, Division of Research.

Aharoni, Y., Tihanyi, L. and Connelly, B. L. 2011. Managerial decision-making in international business: a forty-five-year retrospective. Journal of World Business, 46: 135-142.

Andersson, U., and Holm U. 2007. Managing the Contemporary Multinational: The Role of Headquarters. Cheltenham: Edward Elgar.

Andersson, U., and Holm, U. 2010. Managing the contemporary multinational: the role of headquarters. Cheltenham: Edward Elgar.

Austin, G., Dávila, C., and Jones, G. 2017. The alternative business history: Business in emerging markets. Business History Review, 91(3): 537-569.

Barbero, M. I. 2015. Business groups in nineteenth and twentieth century Argentina. In G. Jones, and A. Lluch (Eds.) 2015. The impact of globalization on Argentina and Chile: business enterprises and entrepreneurship (6-44). Cheltenham: Edward Elgar. 
Barbero, M. I., and Lluch, A. 2015. El capitalismo familiar en Argentina: modelos y dinámicas a largo plazo. In P. Fernández Pérez, and A. Lluch (Eds.), Familias iempresariales y grandes empresas familiars (219-246). Bilbao: Fundación BBVA.

Bartlett, C. A., and Ghoshal, S. 1989. Managing across borders: The transnational solution. Cambridge, MA: Harvard University Press.

Beatty, E. 2003. Approaches to technology transfer in history and the case of nineteenth century Mexico. Comparative Technology Transfer and Society 1(2): 167197.

Beatty, E. 2009. Bottles of beer: the business of technological innovation in Mexico, 1890-1920. Business History Review, 83(2): 317-348.

Becker, M. C., Knudsen, T. and Swedberg, R. (Eds.). 2011. The entrepreneur: Classic texts by Joseph Schumpeter. Stanford: Standford Business Books.

Becker, S. 1998. The German metal traders before 1914. In G. Jones (Ed.). The multinational traders. London: Routledge.

Bedingfield, R. E. 1963. Personality: New vista for platinum King, New York Times, (3 November).

Benito, G. R., Petersen, B., and Welch, L. S. 2009. Towards more realistic conceptualisations of foreign operation modes. Journal of International Business Studies, 40(9): 1455-1470.

Birkinshaw J., Braunerhjelm P., Holm U., and Terjesen S. 2006. Why do some multinational corporations relocate their headquarters overseas? Strategic Management Journal, 27(7): 681-700.

Blanc, H., and Sierra, C. 1999. The internationalisation of R\&D by multinationals: a trade-off between external and internal proximity. Cambridge Journal of Economics, 23(2): 187-206.

Boddewyn, J. J. 1983. Foreign direct divestment theory: Is it the reverse of FDI theory? Review of World Economics, 119(2): 345-355.

Boddewyn, J. J., and Brewer, T. L. 1994. International-business political behaviour: New theoretical directions. Academy of Management Review, 19(1): 119-143.

Bostock, F., and Jones, G. 1994. Foreign multinationals in British manufacturing, 1850-1962. Business History, 36(1): 89-126.

Brown, Rajeswary A. 2000. Chinese big business and the wealth of nations. London: Palgrave.

Buckley, P. (Ed.) 2009. Business history and international business. Business History Special Issue, 51 (3).

Buckley, P. J., and Casson, M. C. 2009. The internalisation theory of the multinational enterprise: A review of the progress of a research agenda after 30 years. Journal of International Business Studies, 40(9): 1563-1580.

Buckley, P. J., Doh, J. P., Benischke, M. H. 2017. Towards a renaissance in international business research? Big questions, grand challenges, and the future of IB scholarship. Journal of International Business Studies, 48(9): 1045-1064. 
Buckley, P., and Casson, M. 1976. The future of the multinational enterprise. London: George Allen and Unwin.

Buckley, P., and Casson, M. 2009. The internalisation theory of the multinational enterprise: A review of the progress of a research agenda after 30 Years. Journal of International Business Studies, 40(9): 1563-1580.

Cage, R. A. (ed.). 1985. The Scots abroad: Labour, capital, enterprise, 1750-1914. London: Croom Helm.

Carlos, A. M., and Nicholas, S. 1998. Giants of an earlier capitalism: The chartered trading companies as modern multinationals. Business History Review, 62(3): 398419.

Carstensen, F. V. 1984. American enterprise in foreign markets: Singer and International Harvester in Imperial Russia. Chapel Hill: The University of North Carolina Press.

Cassis, Y. (Ed.) 1992. Finance and financiers in European history, 1880-1960. Cambridge: Cambridge University Press.

Cassis, Y. 2006. Capital of capitals: The rise and fall of international financial centres. Cambridge: Cambridge University Press.

Cassis, Y., and Minoglou, I. P. (Eds.) 2005. Entrepreneurship in Theory and History New York: Palgrave Macmillan.

Casson, M. 1985. Transaction costs and the theory of the multinational enterprise. New York: Springer.

Casson, M. 1986. General theories of the multinational enterprise: Their relevance to business history. In P. Hertner, and G. Jones (Eds.). Multinationals: Theory and History (42-63). London: Gower.

Casson, M. 1987. The firm and the market: Studies in multinational enterprise and the scope of the firm. Oxford: Blackwell.

Casson, M. 1990. Enterprise and competitiveness. Oxford: Clarendon Press.

Casson, M. 1994. Institutional diversity in international business. Business History, 36(4): 95-108.

Casson, M. 2003. The entrepreneur: An economic theory (Second Edition). Cheltenham: Edward Elgar.

Casson, M., and Casson, C. (Eds.). 2013. History of entrepreneurship: Innovation and risk-taking, 1200-2000. Cheltenham: Edward Elgar.

Casson, M., and Godley, A. 2005. Entrepreneurship and historical explanation. In Y. Cassis and I. P. Monoglou (Eds.). Entrepreneurship in theory and history (25-60). London: Palgrave Macmillan.

Casson, M., and Lopes, T.d.S. 2013. Foreign direct investment in high-risk environments: An historical perspective. Business History, 55(3): 375-404.

Casson, M., Porter, L., and Wadeson, N. 2016. Internalization theory: An unfinished agenda. International Business Review, 25(6): 1223-1234. 
Cavusgil, S. T., and Knight, G. 2015. The born global firm: An entrepreneurial and capabilities perspective on early and rapid internationalization. Journal of International Business Studies, 46(1): 3-16.

Chandler, A. D. 1962. Strategy and structure: Chapters in the history of the industrial enterprise. Cambridge, MA: MIT Press.

Chandler, A. D. 1977. The visible hand. Cambridge, MA: Harvard University Press.

Chandler, A. D. 1990. Scale and scope: The dynamics of industrial capitalism. Cambridge, MA: Harvard University Press.

Chandler, A. D. 1991. The functions of the HQ unit in the multibusiness firm. Strategic Management Journal 12(1): 31-50.

Chandler, A. D., Amatori, F., Hikino, T. (Eds.). 1997. Big business and the wealth of nations. New York: Cambridge University Press.

Chandler, A. D., Sloan, A., and Williamson, O. 1987. The role of the centre. In M. Goold, and A. Campbell (Eds.), Strategies and styles: The role of the centre in managing diversified corporations. Oxford: Basil Blackwell.

Chapman, S. 2003. Merchant enterprise in Britain: From the Industrial Revolution to World War I. Cambridge: Cambridge University Press.

Chiswick, B., and Hatton, T. 2003. International migration and the integration of labor markets. In M. D. Bordo, A. M. Taylor and J. G. Williamson (Eds.). Globalization in historical perspective. Chicago: University of Chicago Press.

Coeurderoy, R., and Verbeke, A. 2016. The unbalanced geography of the world's largest MNEs: Institutional quality and the head office distribution across countries. Global Strategy Journal, 6: 127-148.

Collis, D., Young, D., and Goold, M. 2007. The size, structure and performance of corporate headquarters. Strategic Management Journal, 28(4): 383-405.

Corley, T. A. B. 1983. A History of Burmah Oil Company, 1860-1924. London: Heinemann.

Corley, T. A. B. 1994. Britain's overseas investments in 1914 revisited. Business History, 36(1): 71-88.

Corley, T. A. B. 1998. The free-standing company in theory and practice. In M. Wilkins and H. G. Schröter (Eds.), The free-standing company in the world economy, 1830-1996. Oxford: Oxford University Press.

Cottrell, P. L. 1979. Industrial finance, 1830-1914. London: Methuen.

Criscuolo, P., Narula, R., and Verspagen, B. 2005. Role of home and host country innovation systems in R\&D internationalisation: A patent citation analysis. Economics of Innovation and New Technology, 14(5): 417-433.

Cruz-Fernández, P. A. d. I. 2014. Marketing the hearth: Ornamental embroidery and the building of the multinational Singer sewing machine company. Enterprise \& Society, 15(3): 442-471.

Cyert, R. M., and March, J. G. 1963. A beharioural theory of the firm. Englewood 
Cliffs, NJ: Prentice-Hall.

Davenport-Hines, R. P. T. 1986. Glaxo as a multinational before 1963. In G. Jones (Ed). British Multinationals: Origins, management and performance. Aldershot: Gower.

Davenport-Hines, R. P. T., and Slinn, J. 1992. Glaxo - a History to 1962. Cambridge: Cambridge University Press.

David, T., and Westerhuis, G. (Eds.) 2014. The power of corporate networks: A comparative and historical perspective. London: Routledge.

Davies, R. B. 1969. Peacefully working to conquer the world - The Singer Manufacturing Company in Foreign Markets, 1854-1889. Business History Review, 43(3): 299-325.

Davies, R. B. 1976. Peacefully Working to Conquer the World: Singer Sewing Machines in Foreign Markets, 1854-1920. New York: Arno Press.

Donzé, P. Y., and Kurosawa, T. 2013. Nestlé coping with Japanese nationalism: Political risk and the strategy of a foreign multinational enterprise in Japan, 19131945. Business History, 55(8): 1318-1338.

Duguid, P., and Lopes, T. d. S. 1999. Ambiguous company: Institutions and organization in the port wine trade, 1814-1834. Scandinavian Economic History Review, 47(1): 84-102.

Dunning, J. H. 1993. Multinational enterprise and the global economy. Wokingham: Addison Wesley.

Dunning, J. H. 1998. Location and the multinational enterprise: A neglected factor? Journal of International Business Studies, 19(1): 45-66.

Dunning, J. H. 2009. Location and the multinational enterprise: John Dunning's thoughts on receiving the Journal of International Business Studies 2008 decade award. Journal of International Business Studies, 40(1): 20-34.

Dunning, J. H., and McQueen, M. 1981. The eclectic theory of international production: A case study of the international hotel industry. Managerial and Decision Economics, 2(4): 197-210.

Fear, J. 2008. Cartels. In G. Jones and J. Zeitlin (Eds.), The Oxford Handbook of Business History (268-292). Oxford: Oxford University Press.

Ferrier, R. W. 1982. The history of the British Petroleum Company. Cambridge: Cambridge University Press.

Foss, N. 1997. On the relations of corporate headquarters. Industrial and Corporate Change, 6(2): 313-338.

Gálvez-Muñoz, L., and G. Jones. 2001. Foreign multinationals in the United States. London: Routledge.

Garcia-Ruiz, J., and Toninelli, P. A. 2010. The determinants of entrepreneurship: Leadership, culture, institutions. London: Routledge. 
Ghoshal, S., and Bartlett, C. A. 1990. The multinational corporation as an interorganizational network. The Academy of Management Review, 15(4): 603-625.

Godley, A. 2001. Jewish immigrant entrepreneurship in New York and London, 1880-1914. Basingstoke: Palgrave Macmillan.

Godley, A. 2006. Selling the sewing machine around the world: Singer's international marketing strategies, 1850-1920. Enterprise and Society, 7(2): 266-314.

Halley, Ned. 1990. Two hundred years of Port and Sherry. London: House of Sandeman.

Harlaftis, G., and Minoglou, I. P. (Eds.) 2005. Diaspora entrepreneurial networks: Four centuries of History. Oxford: Berg.

Hatton, T. J., and Williamson, J. G. 1998. The Age of mass migration: Causes and economic impact. New York: Oxford University Press.

Hatton, T. J., and Williamson, J. G. 2002. What fundamentals drive world migration? National Bureau of Economic Research - Working Paper 9159.

Hedlund, G. 1986. The hypermodern MNE - A heterarchy? Human Resource Management, 25(1): 9-35.

Hedlund, G. 1994. A model of knowledge management and the N-Form corporation. Strategic Management Journal, 15: 73-90.

Heer, J. 1966. World events, 1866-1966 - The first hundred years of Nestlé. Vevey: Nestlé.

Heer, J. 1991. Nestlé -125 Years, 1866-1991. Vevey: Nestlé.

Hennart, J.-F. (Ed.). 1982. A theory of multinational enterprise. Cambridge Mass: The University of Michigan Press.

Hennart, J.-F. 1986. Internalization in practice: Early foreign direct investments in Malaysian tin mining. Journal of International Business Studies, 17(2): 131-143.

Hennart, J.-F. 1991. The transaction cost theory of the multinational enterprise. In C. N. Pitelis and R. Sugden (Eds.), The nature of the transnational firm. London: Routledge.

Hennart, J.-F. 1993. The swollen middle: Why most transactions are a mix of "Market" and "Hierarchy". Organizational Science, 4(4): 529-547.

Hennart, J.-F. 1994. The 'comparative institutional' theory of the firm: some implications for corporate strategy. Journal of Management Studies, 31(2): 193-208.

Hennart, J.-F., and Reddy, S. 1997. The choice between mergers/acquisitions and joint ventures: The case of Japanese investors in the United States. Strategic Management Journal, 18(1): 1-12.

Hill, C. W. L., Hwang, P., and Kim, W. C. 1990. An eclectic theory of the choice of international entry mode. Strategic Management Journal, 11(2): 117-128.

Hilleman, J., and Verbeke A. 2014. Internalization theory and the governance of the global factory. In A. Verbeke, R. Van Tulder, and S. Lundan (Eds.), Multinational enterprises, markets and institutional diversity (27-28). New York: Emerald. 
Jensen, N. 2008. Political risk, democratic institutions, and foreign direct investment. The Journal of Politics, 70(4): 1040-1052.

Jones G. 1985. The Gramophone Company: An Anglo-American multinational, 18981931. Business History Review, 59(1): 76-100.

Jones, G. (Ed.) 1986. British multinationals: Origins, management and performance. Aldershot: Gower.

Jones, G. 1981. The state and the emergence of the British oil industry. London: Macmillan.

Jones, G. 1987. The Imperial Bank of Iran and Iranian economic development, 18901952. Business and Economic History, 16: 69-80.

Jones, G. 1988. Foreign multinationals and British industry before 1945. Economic History Review, 41(3): 429-453.

Jones, G. 1993. British multinational banking, 1830-1990. Oxford: Clarendon Press.

Jones, G. 1998. British overseas banks as free-standing companies 1830-1994. In M. Wilkins and H. G. Schröter (Eds.) The free-standing company in the world economy, 1830-1996. Oxford: Oxford University Press.

Jones, G. 2000. Merchants to multinationals. British trading companies in the nineteenth and twentieth centuries. Oxford: Oxford University Press.

Jones, G. 2005a. Multinationals and global capitalism. Oxford: Oxford University Press.

Jones, G. 2005b. Renewing Unilever: Transformation and tradition. Oxford: Oxford University Press.

Jones, G. 2013. Entrepreneurship and multinationals: Global business and the making of the modern world. Northhampton, MA: Edward Elgar.

Jones, G. 2014. Business history and the impact of MNEs on host economies. In Jean Boddewyn (Ed.), Multidisciplinary insights from new AIB Fellows. Bingley: Emerald.

Jones, G., and Atzberger, A. 2015. Hans Wilsdorf and Rolex. Harvard Business School, Boston, MA. 805-138 (rev. Sep 2015).

Jones, G., and Benton, E. R. 2016. Goldfinger: Charles W. Engelhard Jr. and Apartheid-era South Africa. Harvard Business School. 313-148 (rev. Nov.2016).

Jones, G., and Bostock, F. 1996. US multinationals in British manufacturing before 1962. Business History Review, 70(2): 207-256.

Jones, G., and Colpan, A. M. 2016. Business groups, entrepreneurship and the growth of Koç Group in Turkey. Special Issue on Business Groups around the World. Business History, 58(1): 69-88.

Jones, G., and Khanna, T. 2006. Bringing history (back) into international business. Journal of International Business Studies 37(4): 453-468.

Jones, G., and Lluch, A. (Eds.) 2015. The impact of globalization on Argentina and Chile: Business enterprises and entrepreneurship. Cheltenham: Edward Elgar. 
Jones, G., and Lubinski, L. 2012. Managing political risk in global business Beiersdorf, 1914-1990. Enterprise and Society, 13(1): 85-119.

Jones, G., and Pitelis, C. 2015. Entrepreneurial imagination and a demand and supply-side perspective on the MNE and cross-border organization. Journal of International Management, 21(4): 1-13.

Jones, G., and Schröter, H. G. (Eds.) 1993. The rise of multinationals in continental Europe. Aldershot: Edward Elgar.

Jones, G., and Wadhwani, R. D. (Eds.). 2007. Entrepreneurship and global capitalism. Cheltenham: Edward Elgar.

Jones, G., Norris, M., and Kim, S. 2016. Horst Dassler, Adidas, and the Commercialization of Sport. Harvard Business School. 316-007 (rev. June 2016).

Jonker, J., and Zanden, J. L. v. 2007. A history of Royal Dutch Shell (Volume 1). Oxford: Oxford University Press.

Kim, D-W. 1995. J. \& P. Coats in Tsarist Russia, 1889-1917. Business History Review, 69(4): 465-493.

Kim, D-W. 1997. Coats as a multinational before 1914. Business and Economic History, 26(2): 526-539.

Kininmonth, K. W. 2006. The growth, development and management of J. \& P. Coats Ltd, c.1890-1960: An analysis of strategy and structure. Business History, 48(4): 551579.

Kirzner, I. 1973. Competition and entrepreneurship. Chicago: University of Chicago Press.

Kirzner, I. M. 1997. Entrepreneurial discovery and the competitive market process An Austrian approach. Journal of Economic Literature, 35: 60-85.

Knight, F. H. 1921. Risk, uncertainty and profit. Boston: Houghton Mifflin.

Knight, G. G., and Cavusgil, S. T. 1996. The born global firm: a challenge to traditional internaitonlization theory. Advances in International Marketing, 8: 11-26.

Kobrak, C., and Hansen P. (Eds.) 2004. European business, dictatorship and political risk, 1920-1945. New York: Berghahn Books.

Kobrak, C., and Wuestenhagen, J. 2006. International investment and Nazi politics. The cloaking of German assets abroad: 1936-1945. Business History, 48(3): 399- 427.

Kristensen, P. H., and Zeitlin, J. 2004. Local players in global games. Oxford: Oxford University Press.

Kunisch, S., Menz, M., and Ambos, B. 2015. Changes at corporate headquarters: Review, integration, and future research. International Journal of Management Review, 17(3): 356-381.

Kurosawa, T. 2010. Neutral Switzerland and national socialism: The Second World War and the recognition of History. Kyoto: Kyoto University Press. 
Landes, D. E., Mokyr, J., and W. J. Baumol (Eds.) 2010. The invention of enterprise: Entrepreneurship from ancient Mesopotamia to modern times. Princeton: Princeton University Press.

Livesay, H. C. 2000. Andrew Carnegie and the rise of big business. New York: Longman.

Lopes, T. d. S. 1997. Internationacionalização e concentração no vinho do porto. Porto: ICEP/GEHVID.

Lopes, T. d. S. 2007. Global brands: The growth of multinationals in the alcoholic drinks industry. New York: Cambridge University Press.

Lopes, T. d. S. 2010. The entrepreneur, ownership advantages, and the eclectic paradigm. Multinational Business Review, 18(2): $71-87$.

Lopes, T. d. S., and Casson, M. 2007. Entrepreneurship and the development of global brands. Business History Review, 81(4): 651-680.

Lopes, T. d. S., and Casson, M. 2012. Brand protection and globalization of British business. Business History Review, 86(2): 287-310.

Lopes, T. d. S., and Casson, M. 2013. Foreign direct investment in high-risk environments: An historical perspective. Business History, 55(3): 375-404.

Lopes, T. d. S., and Simões, V. C. 2017. Foreign investment in Portugal and knowledge spillovers: From the Methuen Treaty to the $21^{\text {st }}$ Century. Business History, 59(6): 1-29.

Lopes, T. d. S., Guimarães, C. G., Saes, A., and Saraiva, L. F. 2017. The 'disguised' foreign investor. Business History, 59(5): 1-25.

Madsen, T. K., and Servais, P. 1997. The internationlization of born globals: an evolutionary process. International Business Review, 6: 561-583.

Marshall, A. 1920. Principles of economics. London: MacMillan.

Mason, M. 1992. American multinationals and Japan. Cambridge, MA: Harvard University Press.

McCabe, I. B., Harlaftis, G., and Minoglou, I. P. (Eds.). 2005. Diaspora entrepreneurial networks - Four centuries of history. Oxford: Berg.

McCraw, T. K. 1995. Creating modern capitalism. Cambridge, MA: Harvard University Press.

Meyer, K. E., and Benito, G. 2016. Where do MNEs locate their headquarters? At Home! Global Strategy Journal, 6(2): 149-159.

Morck, R., and Yeung, B. 1991. Foreign acquisitions: when do they make sense? Managerial Finance, 17(6): 10-17.

Narula, R., and Santagelo, G. D. 2012. Location and collocation advantages in international innovation. Multinational Business Review, 20(1): 6-25.

Narula, R., and Verbeke, A. 2015. Making internalization theory good for practice: The essence of Alan Rugman's contributions to international business. Journal of World Business, 50(4): 612-622. 
Oonk, G. 2007. Global Indian diasporas: Exploring trajectories of migration and theory. Amsterdam: Amsterdam University Press.

Oviatt, B. M., and McDougall, P.P. 1994. Toward a theory of international new ventures. Journal of International Business Studies, 25(1): 45-64.

Payne, P. 1974. British entrepreneurship in the nineteenth century. London: Macmillan.

Piquet, C. 2004. The Suez company's concession in Egypt, 1854-1956: Modern infrastructure and local economic development. Enterprise \& Society, 5(1): 107-127.

Porter, M. E. 2000. Location, competition, and economic development: local clusters in a global economy. Economic Development Quarterly, 14(1): 15-34.

Porter, M. E., 1998. The competitive advantage of nations. London: MacMillan.

Richardson G. B. 1972. The organisation of industry. The Economic Journal, 82(327): 883-896.

Ridings, E. 1985. Foreign predominance among overseas traders in nineteenth century Latin America. Latin American Research Review, 20(2): 3-27.

Rugman, A. M. 1976. Risk reduction by international diversification. Journal of International Business Studies, 7(2): 75-80.

Rugman, A. M. 1981. A test of internalization theory. Managerial and Decision Eocnomics, 2(4): 211-219.

Rugman, A. M. 2005. The regional multinationals: MNEs and 'Global' Strategic Management. New York: Cambridge University Press.

Rugman, A. M., and Verbeke, A. 1992. A note on the transnational solution and the transaction cost theory of multinational strategic management. Journal of International Business Studies, 23(4): 761-771.

Rugman, A. M., and Verbeke, A. 2003. Extending the theory of the multinational enterprise: Internalization and strategic management perspectives. Journal of International Business Studies, 34(2): 125-137.

Rugman, A. M., and Verbeke, A. 2008. Internalization theory and its impact on the field of international business. In J. J. Boddewyn (Ed.) International business scholarship: AIB fellows on the first 50 years and beyond - Research in global strategic management (vol. 14). Bingley: Emerald.

Rugman, A. M., Verbeke, A., and Yuan W. 2011. Re-conceptualizing Bartlett and Ghoshal's classification of national subsidiary roles in the multinational enterprise. Journal of Management Studies, 48 (2): 253-277.

Schumpeter, J. A. 1934. The theory of economic development: An inquiry into profits, capital, credit, interest and the business cycle. Cambridge, MA: Harvard University Press.

Silva, A. 2014. Organizational innovation in nineteenth century railway investment: Peripheral countries in a global economy. Business History Review, 88(4): 709-36. 
Simson, V., and Jennings, A. 1992. Dishonored games: Corruption, money and greed at the Olympics. Toronto: Spi Books.

Sölvell, Ö., and Zander, I. 1995. The dynamic multinational firm. International Studies of Management and Organization, 25 (1-2): 17-38.

Teece, D. J. 1986. Profiting from technological innovation: Implications for integration, collaboration, licensing and public policy. Research Policy, 15(6): 285305.

The Economist. 2015. Jardine Matheson - Return to China (4 July).

Tomlinson, B. R. 1989. British business in India, 1860-1970. In R. P. T. Davenport Hines and G. Jones (Eds.). British business in Asia since 1860. Cambridge: Cambridge University Press.

Vahlne, J. E., Johanson, J. 2014. Replcacing traditional economics with behavioural assumptions in constructing the Uppsala model: Toward a theory on the evolution of the multinational business enterprise (MBE). In J. J. Boddewyn (Ed.) Multidisciplinary Insights from New AIB Fellows - Research in Global Strategic Management (Vol. 16). Bingley: Emerald.

Verbeke, A. 2003. The evolutionary view of the MNE and the future of internalization theory. Journal of International Business Studies, 34(6): 498-504.

Verbeke, A. 2009. International Business Strategy. Cambridge: Cambridge University Press.

Verbeke, A., and Greidanus, N. 2009. The end of opportunism versus trust debate: Bounded reliability as a new envelope-concept in research on MNE governance. Journal of International Business Studies, 40(9): 1471-1495.

Verbeke, A., and Kano, L. 2012. An internalization theory rationale for MNE regional strategy. Multinational Business Review, 20(2): 135-152.

Verbeke, A., and Kano, L. 2015. The new internalization theory and multinational enterprises from emerging economies: A business history perspective. Business History Review, 42(1): 1-33.

Verbeke, A., Zargarzadeh, M. A., and Osiyevskyym O. 2014. Internalization theory, entrepreneurship and international new ventures. Multinational Business Review, 22(3): 246-269.

Wilkins, M. 1998. Multinational corporations: an historical account. In R. KozulWright and R. Rowthorn (Eds.). Transnational corporations and the global economy (95-133). London: Palgrave Macmillan.

Wilkins, M. 1970. The emergence of multinational enterprise: American business abroad from the colonial era to 1914. Cambridge, MA: Harvard University Press.

Wilkins, M. 1974. The maturing of multinational enterprise: American business abroad from 1914-1970. Cambridge, MA: Harvard University Press.

Wilkins, M. 1977. Modern European economic history and the multinationals. Journal of European Economic History, 6(3): 575-595. 
Wilkins, M. 1988. The free-standing company, 1870-1914: An important type of British foreign direct investment. Economic History Review, 41(2): 259-282.

Wilkins, M. 1989. The history of foreign investment in the United States to 1914. Cambridge, MA: Harvard University Press.

Wilkins, M. 1998. The free-standing company revisited. In M. Wilkins and H. Schröter (Eds.) The free-standing company in the world economy, 1830-1996 (3-66). Oxford: Oxford University Press.

Wilkins, M. 1999. Cosmopolitan finance in the 1920s: New York's emergence as an international financial centre. In R. Sylla, R. Tilly, and G. Tortella (Eds.) The state, the financial system and economic modernization: Comparative historical perspectives (271-91). Cambridge: Cambridge University Press.

Wilkins, M. 2004. Comparative hosts. Business History, 36(1): 18-50.

Wilkins, M. 2004. The history of foreign investment in the US, 1914-1945. Cambridge: Harvard University Press.

Wilkins, M. 2009. Multinational enteprise in insurance: An historical overview. Business History, 51(3): 334-363.

Wilkins, M. 2015. The history of multinationals: A 2015 view. Business History Review, 89(3): 405-414.

Wilkins, M., and Hill, F. E. 1964/2011. American business abroad - Ford in six continents. New York: Cambridge University Press.

Wilkins, M., and Schröter, H. G. (Eds.) 1998. The free-standing company in the world economy, 1830-1996. Oxford: Oxford University Press.

Williamson, O. E. 1975. Markets and Hierarchies: Analysis and Antitrust Implications - A Study in the Economics of Internal Organizations. New York: FreePress, Macmillan.

Williamson, O. E. 1981a. The modern corporation: origins, evolution, attributes. Journal of Economic Literature, 19(4): 1537-1568.

Williamson, O. E. 1981b. The economics of organization: The transaction cost approach. American Journal of Sociology, 87(3): 548-577.

Williamson, O. E. 1996. The mechanisms of governance. New York: Oxford University Press.

Wilson, C. 1954. History of Unilever: a study in economic growth and social change. London: Cassell.

Wilson, C. 1968. Unilever, 1945-1965 - Challenge and response in the post-war Industrial Revolution. London: Cassell.

Wubs, B. 2008. International business and national war interests: Unilever between Reich and Empire, 1939-1945. London: Routledge.

Young, D., and Goold, M. 1999. Effective headquarters staff: A guide to the size, structure and role of corporate headquarters staff in the UK. London: Ashridge Strategic Management Centre. 
Zeitlin, J., 2008. Industrial districts and regional clusters. In G. Jones, and J. Zeitlin (Eds.) The Oxford handbook of business history (219-243). Oxford: Oxford University Press. 